\title{
Antioxidants effects of Platinum Nanoparticles: A Potential AlternativeTreatment to Lung Diseases
}

\author{
Fatimah Yusof, Noor Akmal Shareela Ismail \\ Biochemistry Department, Faculty of Medicine, Universiti Kebangsaan Malaysia Medical Centre, Jalan Yaacob Latif, Bandar Tun Razak, 56000 Kuala \\ Lumpur, Malaysia.
}

\section{ARTICLE INFO}

Article history:

Received on: 20/04/2015

Revised on: 24/05/2015

Accepted on: 19/06/2015

Available online: 27/07/2015

Key words:

antioxidants, platinum

nanoparticles, reactive

oxygen species (ROS),

epithelial sodium channel

$(\mathrm{ENaC})$

\begin{abstract}
Imbalance oxidative status occurs when oxidative stress is higher in the body due to the production of reactive oxygen species. Thus, antioxidants are needed to counteract the production of free radicals. Reoccurrence of oxidative stress in the lung cells will eventually lead to inflammation and edema. This will result to a severe prognosis of lung diseases. Our interest is to populate certain mechanisms that can be activated during this process by reversing the oxidative stress status. Platinum nanoparticles (PtNPs) have been suggested as one of the powerful antioxidants that can quench free radicals. The mechanistic pathway may involve Protein Kinase C, which correlates well with the expression of the Epithelial Sodium Channel (ENaC). ENaC plays an important role in sodium uptake thus stimulate lung liquid clearance. The failure of lung clearance will interrupt gaseous exchange thus eventually lead to death. This review will discuss on the antioxidant properties of PtNPs as well as the underlying mechanism of $\mathrm{PKC}$ and $\mathrm{ENaC}$ in maintaining the oxidative status in the lung cells.
\end{abstract}

\section{INTRODUCTION}

Nanotechnology is growing exponentially with the creation of a variety of products from nanoparticles like silver, titanium, gold, lead, zinc, silicon and platinum. Recent statistic in October, 2013 stated that 1628 of nanotechnology consumer products has been created including 788 health and fitness products (Annonyms, 2013). Nanomaterials can be classified into a few aspects but the main classification is based on the composition and shape (Nair, 2009). Nanomedicine lies under nanotechnology that widely explored by researchers to be one of the solutions in lung cancer's treatment. Metal nanoparticles such as titanium, gold, silver and platinum have been proven to be a potential antioxidant (Table 1). Whilst many extensive researches only focused on the first three metals, platinum nanoparticles (PtNPs) has been given less attention. The presence of antioxidants such as PtNPs is proposed to reduce the effect of reactive oxygen species (ROS). For years, PtNPs have been only used as a catalyst for their high conductivity and reactivity properties in medicine (Cheng et al., 2009). Bimetallic

* Corresponding Author

Noor Akmal Shareela Ismail, Biochemistry Department, Faculty of Medicine, UKM Medical Center, Jalan Yaacob Latif, Bandar Tun Razak, 56000 Kuala Lumpur. Email: nasismail@ukm.edu.my nanoparticles of gold and platinum able to quench superoxide anion and hydrogen peroxide (Kajita et al., 2007). Preliminary results suggested that by giving intranasal administration of PtNPs to a secondhand smokers can inhibit depletion of antioxidant capacity, NFkB activation and neutrophilic inflammation in the mice lung (Onizawa et al., 2009). In addition, the use of PtNPs have been significantly involved in cosmetics and medicine production as an antioxidant (Onizawa et al., 2009). Previous studies report that the PtNPs can act as catalase and superoxide dismutase (SOD) activities which are important antioxidant enzymes against free radical damages. A mixture of palladium and platinum nanoparticles (PAPLAL) accelerated wound healing in aged mice and attenuate skin atrophy in Sod $1^{-/}$mice (Shibuya et al., 2014). PtNPs has significantly reduced the superoxide anion production in an ischemic stroke mice model (Takamiya et al., 2011). This proves that PtNPs produce protective effects against ROS and may play a role in oxidative stress associated with lung diseases. Recently, millions of people have suffered from respiratory related diseases and cancers which contribute to the main lethality worldwide. Cancers which are the abnormal growth of cells can invade other organs in the body at upper stages. Therefore, cancer biomarkers are needed to indicate the progression of the cancers. 
PtNPs may act as electrochemical biosensor to enhance the detection sensitivity and higher accuracy as compared to conventional methods such as ELISA, chromogenic and fluorescence or surface plasmon resonance (Liu, Wang, et al., 2014).

Table 1: The use of metal nanoparticles in nanomedicine.

\begin{tabular}{|c|c|c|c|}
\hline No. & $\begin{array}{c}\text { Metal } \\
\text { Nanoparticles }\end{array}$ & Roles & References \\
\hline 1 & $\begin{array}{l}\text { Titanium } \\
\text { dioxide } \\
\text { nanoparticles }\end{array}$ & $\begin{array}{l}\text { Induce transient pulmonary } \\
\text { inflammation but not lead to } \\
\text { chronic lung disorder }\end{array}$ & $\begin{array}{l}\text { (Yoshiura et } \\
\text { al., 2015) }\end{array}$ \\
\hline 2 & $\begin{array}{l}\text { Titanium } \\
\text { dioxide } \\
\text { nanoparticles }\end{array}$ & $\begin{array}{l}\text { Induce apoptosis and DNA } \\
\text { damage in A549 cells }\end{array}$ & $\begin{array}{l}\text { (Wang et } \\
\text { al., 2014) }\end{array}$ \\
\hline 3 & $\begin{array}{l}\text { Gold } \\
\text { nanoparticles }\end{array}$ & $\begin{array}{l}\text { Mainly used in gold nanoprobe- } \\
\text { based technique which is better } \\
\text { than PCR based techniques for } \\
\text { detecting lung cancer biomarker }\end{array}$ & $\begin{array}{l}\text { (Daraee } \text { et } \\
\text { al., 2015) }\end{array}$ \\
\hline 4 & $\begin{array}{l}\text { Glucose-coated } \\
\text { gold } \\
\text { nanoparticles }\end{array}$ & $\begin{array}{l}\text { Enhance better cancer killing } \\
\text { compare to X-ray or AuNPs } \\
\text { alone }\end{array}$ & $\begin{array}{l}\text { (Hu et al., } \\
\text { 2015) }\end{array}$ \\
\hline 5 & $\begin{array}{l}\text { Gold } \\
\text { nanoparticles }\end{array}$ & $\begin{array}{l}\text { Reduce cell viability and induce } \\
\text { oxidative stress in } \mathrm{C} 2 \mathrm{Cl} 2 \\
\text { myoblast cells }\end{array}$ & $\begin{array}{l}\text { (Wahab et } \\
\text { al., 2014) }\end{array}$ \\
\hline 6 & $\begin{array}{l}\text { Silver and gold } \\
\text { nanoparticles }\end{array}$ & $\begin{array}{l}\text { Increase ROS and deplete } \\
\text { antioxidant enzymes status in } \\
\text { erythrocytes and tissues }\end{array}$ & $\begin{array}{l}\text { (Shrivastava } \\
\text { et al., } \\
\text { 2014) }\end{array}$ \\
\hline 7 & $\begin{array}{l}\text { Silver } \\
\text { nanoparticles }\end{array}$ & Antibacterial agents & $\begin{array}{l}\text { (Franci et } \\
\text { al., 2015) }\end{array}$ \\
\hline 8 & $\begin{array}{l}\text { Silver } \\
\text { nanoparticles }\end{array}$ & $\begin{array}{l}\text { Induce oxidative stress in bone } \\
\text { marrow cell of rats }\end{array}$ & $\begin{array}{l}\text { (Patlolla et } \\
\text { al., 2015) }\end{array}$ \\
\hline 9 & $\begin{array}{l}\text { Silver } \\
\text { nanoparticles }\end{array}$ & Induce rat motor dysfunction & $\begin{array}{l}\text { (Yin et al., } \\
2015)\end{array}$ \\
\hline 10 & $\begin{array}{l}\text { Silver } \\
\text { nanoparticles }\end{array}$ & $\begin{array}{l}\text { Small size AuNP are cytototoxic } \\
\text { to BEAS-2B human lung cells }\end{array}$ & $\begin{array}{l}\text { (Gliga } \text { et } \\
\text { al., 2014) }\end{array}$ \\
\hline 11 & $\begin{array}{l}\text { Silver } \\
\text { nanoparticles }\end{array}$ & $\begin{array}{l}\text { Induce strong toxicity, reduce cell } \\
\text { viability and increase LDH } \\
\text { release in A549 human lung cells }\end{array}$ & $\begin{array}{l}\text { (Lee } \text { et al., } \\
\text { 2011) }\end{array}$ \\
\hline
\end{tabular}

Surgery, chemotherapy and radiotherapy has been the most common practices to treat cancers. Chemotherapy is considered the most successful when a sufficient concentration of effective drug concoctions are delivered to the tumor cells without causing intolerable toxicity effects to the patients. (Mohammadi et al., 2013). In radiotherapy treatment, radiosensitizers are used in order to make tumor cells more sensitive to the therapy thus killing the cancer cells. AuNPs have been used as a radiosensitizer together with $\mathrm{x}$-ray radiation. However, PtNPs can be used with combination of hadron therapy that can enhance double strands breaking DNA better than AuNPs with x-ray (Porcel et al., 2010). This can be complementary to DNA glycosylase mechanism to accelerate the reconstruction of new DNA, as its activity in lung cancer tissues are relatively low in comparison to the normal lung tissues (Sarker et al., 2014). A small size of 20nm has shown an antioxidant effect of PtNPs, which exhibit better catalytic activity than larger particles because of their larger surface area and the presence of atoms on the surface (Konieczny et al., 2013; Magdolenova et al., 2013). Nevertheless, the use of appropriate size needs to be addressed to avoid a toxicity effect to certain organs. The size that toxic to the cell is different among various metal nanoparticles. PtNPs exposure of less than $1 \mathrm{~nm}$ in mice can induce renal injury, but the effects of this injury can be reduced by increasing the size nanoparticles (Yamagishi et al., 2013). Meanwhile, $1 \mathrm{~nm}$ PtNPs has been proven to scavenge superoxide anion radical as compared to $5 \mathrm{~nm}$ (Hamasaki et al., 2008). However, smaller size of PtNPs did not influence in the gene expression in various organs of rats (Katao et al., 2011).

Table 2 : Roles of platinum nanoparticles in nanomedicine.

\begin{tabular}{|c|c|c|c|}
\hline No & $\begin{array}{l}\text { Platinum } \\
\text { related } \\
\text { research }\end{array}$ & Roles & References \\
\hline 1 & $\begin{array}{l}\text { Palladium and } \\
\text { platinum } \\
\text { nanoparticles }\end{array}$ & $\begin{array}{l}\text { Treat aging-related skin } \\
\text { diseases }\end{array}$ & $\begin{array}{l}\text { (Shibuya et } \\
\text { al., 2014) }\end{array}$ \\
\hline 2 & $\begin{array}{l}\text { Platinum } \\
\text { nanoparticles }\end{array}$ & $\begin{array}{l}\text { Scavenge ROS on blood } \\
\text { vessel mimicking } \\
\text { microfluidic chip }\end{array}$ & $\begin{array}{l}\text { (Zheng et al., } \\
\text { 2014) }\end{array}$ \\
\hline 3 & $\begin{array}{l}\text { Platinum } \\
\text { nanoparticles }\end{array}$ & $\begin{array}{l}\text { Inhibit DNA double-strand } \\
\text { scission by degradation of } \\
\text { ROS }\end{array}$ & $\begin{array}{l}\text { (Panikkanvala } \\
\text { ppil et al., } \\
\text { 2013) }\end{array}$ \\
\hline 4 & $\begin{array}{l}\text { Platinum } \\
\text { nanoparticles }\end{array}$ & $\begin{array}{l}\text { Anti-inflammatory effects on } \\
\text { lipopolysaccaride in RAW } \\
264.7 \text { macrophages }\end{array}$ & $\begin{array}{l}\text { (Rehman et } \\
\text { al., 2012) }\end{array}$ \\
\hline 5 & $\begin{array}{l}\text { Platinum } \\
\text { nanoparticles }\end{array}$ & $\begin{array}{l}\text { Neurobehavioral and } \\
\text { neuroprotective effects on } \\
\text { ischemic stroke }\end{array}$ & $\begin{array}{l}\text { (Takamiya et } \\
\text { al., 2011) }\end{array}$ \\
\hline 6 & $\begin{array}{l}\text { Platinum } \\
\text { nanoparticles }\end{array}$ & $\begin{array}{l}\text { Reduce ROS production from } \\
\text { UV-light-induced epidermal } \\
\text { inflammation }\end{array}$ & $\begin{array}{l}\text { (Yoshihisa et } \\
\text { al., 2010) }\end{array}$ \\
\hline 7 & $\begin{array}{l}\text { Platinum } \\
\text { nanoparticles }\end{array}$ & $\begin{array}{l}\text { Inhibit pulmonary } \\
\text { inflammation }\end{array}$ & $\begin{array}{l}\text { (Onizawa et } \\
\text { al., 2009) }\end{array}$ \\
\hline 8 & $\begin{array}{l}\text { Platinum } \\
\text { nanoparticles }\end{array}$ & $\begin{array}{l}\text { Decrease oxygen species in } \\
\text { cells and increase cells } \\
\text { viability during stress }\end{array}$ & $\begin{array}{l}\text { (Zhang et al., } \\
\text { 2009) }\end{array}$ \\
\hline 9 & $\begin{array}{l}\text { Platinum } \\
\text { nanoparticles }\end{array}$ & $\begin{array}{l}\text { Scavenge superoxide anion } \\
\text { and hydroxyl radical }\end{array}$ & $\begin{array}{l}\text { (Hamasaki et } \\
\text { al., 2008) }\end{array}$ \\
\hline 10 & $\begin{array}{l}\text { Platinum } \\
\text { nanoparticles }\end{array}$ & $\begin{array}{l}\text { Extend the lifespan of } \\
\text { C.elegans }\end{array}$ & $\begin{array}{l}\text { (Kim et al., } \\
\text { 2008) }\end{array}$ \\
\hline 11 & $\begin{array}{l}\text { Gold and } \\
\text { platinum } \\
\text { nanoparticles }\end{array}$ & $\begin{array}{l}\text { Scavenge superoxide anion } \\
\text { and hydrogen peroxide }\end{array}$ & $\begin{array}{l}\text { (Kajita et al., } \\
\text { 2007) }\end{array}$ \\
\hline
\end{tabular}

Where studies on the identification of PtNPs potential in nanomedicine are still ongoing, we cannot miss any possible side effects that may be caused by PtNPs. To date, findings have shown that no hydroxyl radicals was formed when PtNPs are mixed with hydrogen peroxide (Okamoto et al., 2012). PtNPs also produce a better result in reversing oxidative stress in bronchiolar cell lines as compared to another metal nanoparticles (Schmidt et al., 2007). PtNPs treatment to the adherent cells human have shown no cytotoxicity effects to various cell lines including diploid embryonic lung fibroblasts (TIG-1), human diploid fibroblasts (WI-38), human diploid embryonic lung cell lines (MRC-5), cervical carcinoma cells (HeLa) and human hepatocellular carcinoma cell lines (HepG2) (Hamasaki et al., 2008). To further demonstrate its safety, PtNPs have been used as a commercial supplement product after being approved by Ministry of Health, Labour and Welfare of Japan (Onizawa et al., 2009). Whilst the effects of PtNPs in vitro are promising, its activation through a specific mechanism to treat lung diseases needs to be elucidated. Hereby, we are proposing the antioxidant properties of PtNPs in reversing oxidative stress through epithelial sodium channel 
$(\mathrm{ENaC})$ especially in the lung cells. Earlier studies have demonstrated that inflammation of the lungs may cause reduction in $\mathrm{ENaC}$ activity that lead to a severe edema prognosis (Suzuki et al., 2004; Dagenais et al., 2005) . Therefore, ENaC is suggested as an important indicator to link with the redox status upon treatment of PtNPs.

\section{EPITHELIAL SODIUM CHANNEL (ENaC)}

$\mathrm{ENaC}$ is expressed in the apical plasma membrane of lung epithelial, kidney, tongue and bladder. ENaC plays an important role in mediating $\mathrm{Na}^{+}$absorption in the epithelail cells. In lung cells, increased pulmonary edema has shown to be reduced thus affecting $\mathrm{Na}^{+}$absorption through the alveolar ENaC (Bhalla \& Hallows 2008). ENaC is composed of three homologous subunits which are alpha $(\alpha)$, beta $(\beta)$ and gamma $(\gamma)$ (Figure 1). Each subunits has an amino $(\mathrm{N})$ and carboxyl $(\mathrm{C})$ intracellular instead of two membrane domains connected by a large extracellular loop (Hughey et al., 2004). Each subunits has homologous structure and the three subunits share $30 \%$ similarity in amino acids sequences. All three subunits are required to form a fully functional channel. $\alpha$-subunit of $\mathrm{ENaC}$ is the main pore formation subunit while $\beta$-ENaC and $\gamma$-ENaC are based on the selection. $\alpha-\mathrm{ENaC}$ can be constituted alone however maximum potential can be seen when all subunits were expressed altogether (Bruns et al., 2003, Ismail et al., 2014).

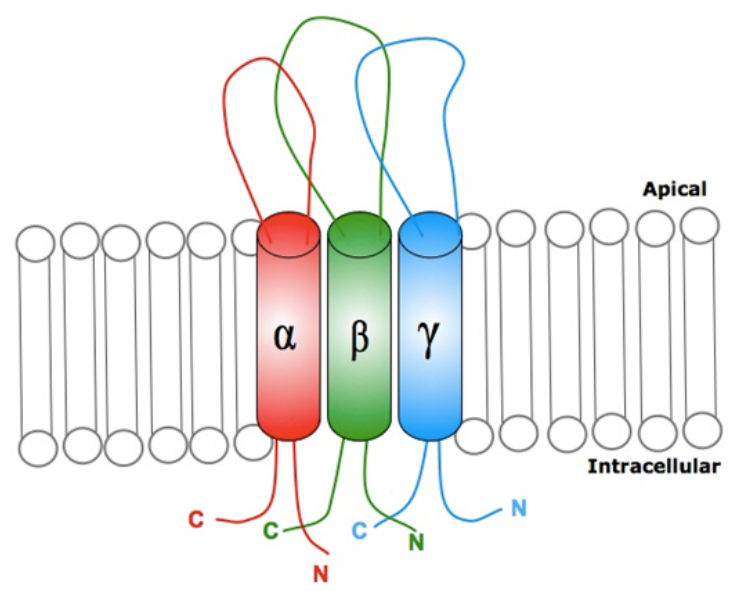

Fig. 1: The classical epithelium sodium channel $(\mathrm{ENaC})-\mathrm{ENaC}$ is composed of three subunits: $\alpha-, \beta$-, and $\gamma$ - which each have an intracellular carboxy (C) and amino $(\mathrm{N})$ terminal.

$\mathrm{ENaC}$ protein that consist of $\mathrm{N}$ and $\mathrm{C}$ terminals together play a role in the surface of the cells. $\mathrm{N}$ terminal of $\alpha-\mathrm{ENaC}$ is required for maximum activity, while $\beta$-ENaC and $\gamma$-ENaC are required in determining the half-life channel (Staub et al., 1997). Amino acids in each subunits in the extracellular domain distinguishes $\mathrm{ENaC}$ function to ensure the utility domain in which each subunit can interact with the extracellular solution. This involves the process of glycosylation (Rotin et al., 2001) and amiloride binding (Benos 1982) which specifically exists in the $\alpha$ subunit of ENaC (Berdiev et al., 1998). C-terminal transmembrane domain face extracellular serine-proteases which leads to the activation of $\mathrm{ENaC}$ which linked by the linker region located in the catalytic domain to allow $\mathrm{ENaC}$ interaction against other proteins on the cell surface (Hooper et al., 2001). This region also contains internalization proline-rich (PY) motif sequences. Deletion of PY-motif will enhance ENaC activity and this will lead to Liddle syndrome symptoms (Abriel et al., 1999; Rotin et al., 2001). ENaC stability can be regulated by lysine acetylation as this will antagonize $\mathrm{ENaC}$ ubiquitination (Butler et al., 2015). Duration for the channel to open and the density of functional channels are two important factors that can alter the regulation of $\mathrm{ENaC}$. The open probability of $\mathrm{ENaC}$ increasas three-fold in PKC- $\alpha$ knockout mice compare to wild type mice (Bao et al., 2014). The current finding has shed some light on the relationship of PKC and $\mathrm{ENaC}$ activity.

\section{PKC PATHWAY}

Protein kinases are enzymes that regulate the function of proteins through the addition and elimination of phosphate groups. This will cause changes in enzyme activity. Some of the protein kinases that involved in ENaC expressions are PKA (Blazer-Yost et al., 2003; Snyder et al., 2004; Liang et al., 2010; Ismail et al., 2014), PKB (Mansley\&Wilson 2010; Watt et al., 2012; Ismail et al., 2014) and P-13 kinase (Mansley\&Wilson 2010; Watt et al., 2012; Ismail et al., 2014). Another important protein kinase that involves in carcinogen signalling pathways is Protein Kinase $\mathrm{C}$ (PKC). PKC regulates the function of other proteins through phosphorylation of hydroxyl groups on the amino acid serine (Ser) and threonine (Thr) (Figure 2). Bao et al., (2014) reported that phosphorylation of Myristoylated alanine-rich C-kinase (MARCKS) by PKC $\alpha$ causes this protein to leave the membrane and does not sequester $\mathrm{PIP}_{2}$ to ENaC thus causing open probability of $\mathrm{ENaC}$ to decrease. PKC signaling through activation of MAPK1/2 in A6 cells has lead to the degradation of $\gamma$-ENaC (Booth\&Stockand 2003). PKC also involves in the regulation of lung liquid volume and inhibit ENaC activity. When PKC activators, phorbol 12-myristate 13-acetate (PMA) and $\mathrm{Ca}^{2+}$ ionophore ionomycin generate simultaneously into the lungs, the movement of transepithelial fluid lungs decreases significantly but the decreases is blocked by PKC inhibitors, chelerythrine chloride and GF109203X (Soukup et al., 2012). Hypoxia-inducible factor (HIF) also regulates heme-oxidized IRP2 ubiquitin ligase $1 \mathrm{~L}$ (HOIL-1L) that function similarly as $\mathrm{PKC} \zeta$ ubiquitin ligase to promote lung tumor growth (Queisser et al., 2014). Thus, research nowadays need to explore more about the inhibitor of the PKC isoforms that can be applied to chemotherapy and radiotherapy without giving adverse effects to the patients (Fan et al., 2013). The upregulation of PKC will reduce the expression of ENaC. M2 transmembrane protein can enhance ROS production and stimulate $\mathrm{PKC}$ but the protein can reduce $\mathrm{ENaC}$ expression by promoting endocytosis and proteosome degradation (Lazrak et al., 2009). Thus, antioxidant characteristic of PtNPs will help to counteract the oxidative stress formed during the inflammation thus downregulate the $\mathrm{PKC}$ and $\mathrm{ENaC}$. 


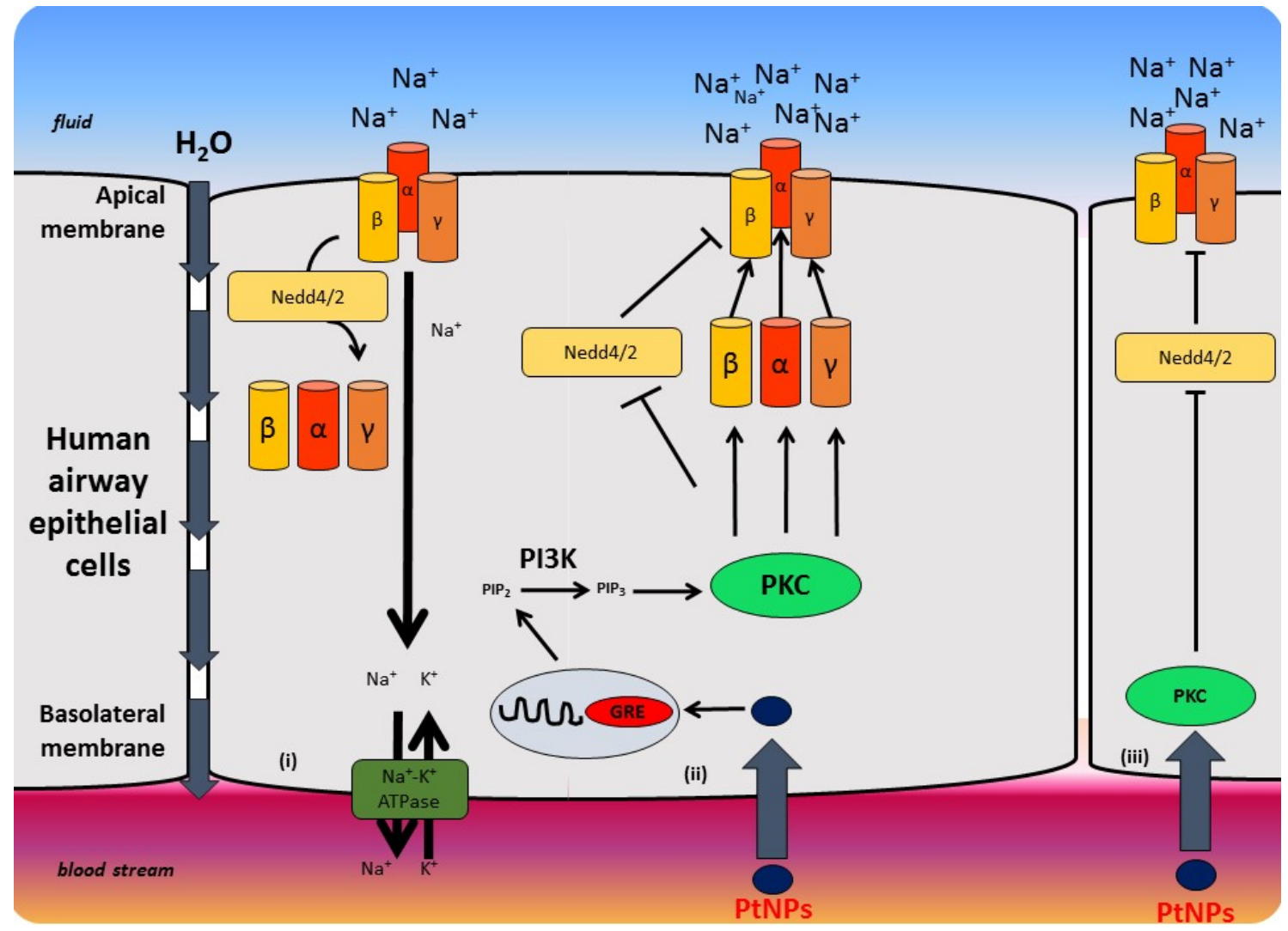

Fig. 2: Diagram showing the regulation of ENaC in three different conditions.

(i) basal condition, where ENaC subunits at the cell surface are normally expressed and further internalised by Nedd4-2; (ii) activation of ENaC and deactivation of Nedd4-2 by the effect of PtNPs, through PKC activity and (iii) activation of ENaC and deactivation of Nedd4-2 by the PKC pathway.

\section{CONCLUSION}

PtNPs may provide as an alternative carrier drug to oxidative stress-related diseases through more effective methods and to produce less effects to the body system. Thus, it is worthy to study the mechanistic pathway related to PtNPs hence to strengthen its contribution to the nanomedicine field. The study on $\mathrm{ENaC}$ is important to understand further about the rate of fluid absorption in the lungs and thus reducing respiratory problems caused by oxidative stress. PtNPs need to be demonstrated as an antioxidant agent that can reduce the effects of ROS.

PtNPs may reverse the oxidative imbalance and in subsequent will affect $\mathrm{ENaC}$ activity by downregulating $\mathrm{PKC}$ in the lung cells thus will act as a potentially alternative treatment to treat lung diseases.

\section{ACKNOWLEDGEMENTS}

We would like to thank the members of Biochemistry Department, Faculty of Medicine for helpful discussions. The authors have no competing financial interests in relation to this work. This work is supported by Ministry of Education, Malaysia (FR GS/1/2013/SKK01/UKM/03/1).

\section{REFERENCES}

Abriel H, Loffing, J, Rebhun, JF, Pratt JH, Schild L, Horisberger JD, Rotin D, Staub O. Defective Regulation of the Epithelial $\mathrm{Na}+$ Channel by Nedd4 in Liddle's Syndrome. J of Clin Invest, 1999; 103(5): 667.

Anonyms. 2013. Project on Emerging Nanotechnologies. Inventory of Nanotechnology-Based Cansumer Product.

Bao HF, Thai TL, Yue Q, Ma HP, Eaton AF, Cai H, Klein JD, Sands JM, Eaton DC. ENaC Activity Is Increased in Isolated, Split-Open Cortical Collecting Ducts from Protein Kinase $\mathrm{C} \alpha$ Knockout Mice. Am J Physio-Renal Physio, 2014; 306(3): F309-F320.

Benos DJ. Amiloride: A Molecular Probe of Sodium Transport in Tissues and Cells. Am J Physiol-Cell Physiol, 1982; 242(3): C131C145.

Berdiev BK, Karlson KH, Jovov B, Ripoll PJ, Morris R, Loffing-Cueni D, Halpin P, Stanton BA, Kleyman TR, Ismailov II. Subunit Stoichiometry of a Core Conduction Element in a Cloned Epithelial Amiloride-Sensitive $\mathrm{Na}<\mathrm{Sup}>+</$ Sup $>$ Channel. Biophy J 1998; 75(5): 2292-2301.

Bhalla V \& Hallows KR. Mechanisms of ENaC Regulation and Clinical Implications. J Am Soc Nephrol, 2008; 19(10): 1845-1854.

Blazer-Yost BL, Esterman MA, Vlahos CJ Insulin-Stimulated Trafficking of Enac in Renal Cells Requires Pi 3-Kinase Activity. Am J Physiol-Cell Physiol, 2003; 284(6): C1645-C1653.

Booth RE, Stockand JD. Targeted Degradation of Enac in Response to Pkc Activation of the Erk1/2 Cascade. Am J Physiol-Renal Physiol, 2003; 284(5): F938-F947. 
Bruns JB, Hu B, Ahn YJ, Sheng S, Hughey RP, Kleyman TR. Multiple Epithelial $\mathrm{Na}+$ Channel Domains Participate in Subunit Assembly. Am J Physiol-Renal Physiol, 2003; 285(4): F600-F609.

Butler PL, Staruschenko A., Snyder PM. Acetylation Stimulates the Epithelial Sodium Channel by Reducing Its Ubiquitination and Degradation. J Biol Chem, 2015; M114. 635540.

Cheng H, Xi C, Meng X, Hao Y, Yu Y, Zhao F. Polyethylene Glycol-Stabilized Platinum Nanoparticles: The Efficient and Recyclable Catalysts for Selective Hydrogenation of $<\mathrm{I}>\mathrm{O}</ \mathrm{I}>$-Chloronitrobenzene to $<\mathrm{I}>\mathrm{O}</ \mathrm{I}>$-Chloroaniline. J Coll interface Sc, 2009; 336(2): 675-678.

Dagenais A, Gosselin D, Guilbault C, Radzioch D, Berthiaume Y. Modulation of Epithelial Sodium Channel $(\mathrm{ENaC})$ Expression in Mouse Lung Infected with Pseudomonas Aeruginosa. Respir Res, 2005; 6(2): doi:10.1186/1465-9921-6-2

Daraee H, Pourhassanmoghadam M, Akbarzadeh A, Zarghami N, Rahmati-Yamchi M. Gold Nanoparticle-Oligonucleotide Conjugate to Detect the Sequence of Lung Cancer Biomarker. Art cells, Nanomed Biotech, 2015; ahead-of-print: 1-7.

Fan C, Li Y, Jia J. Protein Kinase Cs in Lung Cancer: A Promising Target for Therapies. J Cancer Res Therapeu, 2013; 9(5): 74.

Franci G, Falanga A, Galdiero S, Palomba L, Rai M, Morelli G, Galdiero M. Silver Nanoparticles as Potential Antibacterial Agents. Mol, 2015; 20(5): 8856-8874.

Gliga AR, Skoglund S, Wallinder IO, Fadeel B, Karlsson HL. Size-Dependent Cytotoxicity of Silver Nanoparticles in Human Lung Cells: The Role of Cellular Uptake, Agglomeration and Ag Release. Part Fibre Toxicol, 2014; 11(11): 1-17.

Hamasaki T, Kashiwagi T, Imada T, Nakamichi N, Aramaki S, Toh K, Morisawa S, Shimakoshi H, Hisaeda Y, Shirahata S. Kinetic Analysis of Superoxide Anion Radical-Scavenging and Hydroxyl RadicalScavenging Activities of Platinum Nanoparticles. Langmuir, 2008; 24(14): 7354-7364.

Hooper JD, Clements JA, Quigley JP, Antalis T. M.Type II Transmembrane Serine Proteases Insights into an Emerging Class of Cell Surface Proteolytic Enzymes. J Biol Chem, 2001; 276(2): 857-860.

$\mathrm{Hu}$ C, Niestroj M, Yuan D, Chang S, Chen J. Treating Cancer Stem Cells and Cancer Metastasis Using Glucose-Coated Gold Nanoparticles. Int J Nanomed, 2015; 10 :2065-77.

Hughey RP, Bruns JB, Kinlough CL, Kleyman TR. Distinct Pools of Epithelial Sodium Channels Are Expressed at the Plasma Membrane. J Biol Chem, 2004; 279(47): 48491-48494.

Ismail NA, Baines DL, Wilson SM. The Phosphorylation of Endogenous Nedd4-2 in Na+-Absorbing Human Airway Epithelial Cells. Euro J Pharmacol, 2014; 732(32-42).

Kajita M, Hikosaka K, litsuka M, Kanayama A, Toshima N, Miyamoto Y. Platinum Nanoparticle Is a Useful Scavenger of Superoxide Anion and Hydrogen Peroxide. Free Radical Res, 2007; 41(6): 615-626.

Katao K, Honma R, Kato S, Watanabe S, Imai J. Influence of platinum nanoparticles orally administered to rats evaluated by systemic gene expression profiling. Exp Anim, 2011: 60(1):33-45.

Kim J, Takahashi M, Shimizu T, Shirasawa T, Kajita M, Kanayama A, Miyamoto Y. Effects of a Potent Antioxidant, Platinum Nanoparticle, on the Lifespan of Caenorhabditis Elegans. Mech Ageing Dev, 2008; 129(6): 322-331.

Konieczny P, Goralczyk AG, Szmyd R, Skalniak L, Koziel J, Filon FL, Crosera M, Cierniak A, Zuba-Surma EK, Borowczyk J. Effects Triggered by Platinum Nanoparticles on Primary Keratinocytes. Itnl J Nanomed, 2013; 8(3963).

Lazrak A, Iles KE, Liu G, Noah DL, Noah JW, Matalon S. Influenza Virus M2 Protein Inhibits Epithelial Sodium Channels by Increasing Reactive Oxygen Species. FASEB J, 2009; 23(11): 3829-3842.

Lee YS, Kim DW, Lee YH, Oh JH, Yoon S, Choi MS, Lee SK, Kim JW, Lee K, Song CW. Silver Nanoparticles Induce Apoptosis and G2/M Arrest Via Pkc $\zeta$-Dependent Signaling in A549 Lung Cells. Arch Toxicol, 2011; 85(12): 1529-1540.

Liang X, Butterworth MB, Peters KW, Frizzell RA. As160 Modulates Aldosterone-Stimulated Epithelial Sodium Channel Forward Trafficking. Mol Biol Cell, 2010; 21(12): 2024-2033.
Liu N, Wang Z, Ma Z. Platinum Porous Nanoparticles for the Detection of Cancer Biomarkers: What Are the Advantages over Existing Techniques? Bioanalysis, 2014; 6(7): 903-905.

Liu Z, Wu Y, Guo Z, Liu Y, Shen Y, Zhou P, Lu X. 2014. Effects of Internalized Gold Nanoparticles with Respect to Cytotoxicity and Invasion Activity in Lung Cancer Cells. PloS one, 2014; 9(6): e99175.

Magdolenova Z, Drlickova M, Henjum K, Rundén-Pran E, Tulinska J, Bilanicova D, Pojana G, Kazimirova A, Barancokova M, Kuricova M. Coating-Dependent Induction of Cytotoxicity and Genotoxicity of Iron Oxide Nanoparticles. Nanotoxicol, 2013; 0): 113.

Mansley MK, Wilson SM. Effects of Nominally Selective Inhibitors of the Kinases Pi3k, Sgk1 and Pkb on the Insulin-Dependent Control of Epithelial $\mathrm{Na}^{+}$Absorption. Brit J Pharmacol, 2010; 161(3): 571-588.

Mohammadi H, Abedi A, Akbarzadeh A, Mokhtari MJ, Shahmabadi HE, Mehrabi MR, Javadian S, Chiani M. Evaluation of Synthesized Platinum Nanoparticles on the Mcf-7 and Hepg-2 Cancer Cell Lines. Int Nano Lett, 2013; 3(1): 1-5.

Okamoto H, Horii K, Fujisawa A, Yamamoto Y. Oxidative Deterioration of Platinum Nanoparticle and Its Prevention by Palladium. Exp Dermatol, 2012; 21(s1): 5-7.

Onizawa S, Aoshiba K, Kajita M, Miyamoto Y, Nagai A. Platinum Nanoparticle Antioxidants Inhibit Pulmonary Inflammation in Mice Exposed to Cigarette Smoke. Pulm Pharmacol Therap, 2009; 22(4): 340-349.

Panikkanvalappil SR, Mahmoud MA, Mackey MA, El-Sayed MA. Surface-Enhanced Raman Spectroscopy for Real-Time Monitoring of Reactive Oxygen Species-Induced DNA Damage and Its Prevention by Platinum Nanoparticles. ACS nano, 2013; 7(9): 7524-7533.

Patlolla AK, Hackett D, Tchounwou PB. Genotoxicity Study of Silver Nanoparticles in Bone Marrow Cells of Sprague-Dawley Rats. Food Chem Toxicol, 2015; doi: 10.1016/j.fct.2015.05.005.

Porcel E, Liehn S, Remita H, Usami N, Kobayashi K, Furusawa Y, Le Sech C, Lacombe S. Platinum Nanoparticles: A Promising Material for Future Cancer Therapy? Nanotech, 2010; 21(8): 085103.

Queisser MA, Dada LA, Deiss-Yehiely N, Angulo M, Zhou G, Kouri FM, Knab LM, Liu J, Stegh AH, Decamp MM. Hoil-11 Functions as the Pkc $\zeta$ Ubiquitin Ligase to Promote Lung Tumor Growth. Am J Resp Crit Care Med, 2014; 190(6): 688-698.

Rehman MU, Yoshihisa Y, Miyamoto Y, Shimizu T. The Anti-Inflammatory Effects of Platinum Nanoparticles on the Lipopolysaccharide-Induced Inflammatory Response in Raw 264.7 Macrophages. Inflamm Res, 2012; 61(11): 1177-1185.

Rotin D, Kanelis V, Schild L. Trafficking and Cell Surface Stability of ENaC. Am J Physiol-Renal Physiol, 2001; 281(3): F391F399.

Sarker AH, Chatterjee A, Williams M, Lin S, Havel C, Jacob Iii P, Boldogh I, Hazra TK, Talbot P, Hang B. Neil2 Protects against Oxidative DNA Damage Induced by Sidestream Smoke in Human Cells. PloS One, 2014; 9(3): e90261.

Schmid M, Zimmermann S, Krug HF, Sures B. Influence of Platinum, Palladium and Rhodium as Compared with Cadmium, Nickel and Chromium on Cell Viability and Oxidative Stress in Human Bronchial Epithelial Cells. Env Itnl, 2007; 33(3): 385390.

Shibuya S, Ozawa Y, Watanabe K, Izuo N, Toda T, Yokote K, Shimizu T. Palladium and Platinum Nanoparticles Attenuate AgingLike Skin Atrophy Via Antioxidant Activity in Mice. PloS One, 2014; DOI: 10.1371/journal.pone.0109288

Shrivastava R, Kushwaha P, Bhutia YC, Flora S. Oxidative Stress Induced Following Exposure to Silver and Gold Nanoparticles in Mice. Toxicol Ind Health, 2014; pii0748233714562623.

Snyder PM, Olson DR, Kabra R, Zhou R, Steines JC. Camp and Serum and Glucocorticoid-Inducible Kinase (Sgk) Regulate the Epithelial $\mathrm{Na}^{+}$Channel through Convergent Phosphorylation of Nedd4-2. J Biol Chem, 2004; 279(44): 45753-45758. 
Soukup B, Benjamin A, Orogo-Wenn M, Walters, D. Physiological Effect of Protein Kinase C on Enac-Mediated Lung Liquid Regulation in the Adult Rat Lung. Am J Physiol-Lung Cell Mol Physiol, 2012; 302(1): L133-L139.

Staub O, Gautschi I, Ishikawa T, Breitschopf K, Ciechanover A, Schild L, Rotin D. Regulation of Stability and Function of the Epithelial $\mathrm{Na}^{+}$Channel (Enac) by Ubiquitination. EMBO J, 1997; 16(21): 63256336.

Suzuki S, Matsuda Y, Sugawara T, Tabata T, Ishibashi H, Hoshikawa Y, Kubo H, Kondo T. Effects of Carbenoxolone on Alveolar Fluid Clearance and Lung Inflammation in the Rat. Crit Care Med, 2004; 32(9): 1910-1915.

Takamiya M, Miyamoto Y, Yamashita T, Deguchi K, Ohta Y, Ikeda Y, Matsuura T, Abe K. Neurological and Pathological Improvements of Cerebral Infarction in Mice with Platinum Nanoparticles. J Neurosci Res, 2011; 89(7): 1125-1133.

Wahab R, Dwivedi S, Khan F, Mishra YK, Hwang I, Shin HS, Musarrat J, Al-Khedhairy AA. Statistical Analysis of Gold NanoparticleInduced Oxidative Stress and Apoptosis in Myoblast (C2c12) Cells. Colloids and Surfaces B: Biointerfaces, 2014; 123(664-672).

WangY, Cui H, Zhou J, Li F, Wang J, Chen M, Liu Q. Cytotoxicity, DNA Damage, and Apoptosis Induced by Titanium Dioxide Nanoparticles in Human Non-Small Cell Lung Cancer A549 Cells. Env Sci and Poll Res, 2014; 22(7): 5519-5530.

Watt GB, Ismail NA, Caballero AG, Land SC, Wilson SM. Epithelial $\mathrm{Na}^{+}$Channel Activity in Human Airway Epithelial Cells: The Role of Serum and Glucocorticoid-Inducible Kinase 1. Brit J Pharmacol, 2012; 166(4): 1272-1289.

Yamagishi Y, Watari A, Hayata Y, Li X, Kondoh M, hioka Y, Tsutsumi Y, Yagi K. Acute and Chronic Nephrotoxicity of Platinum Nanoparticles in Mice. Nanoscale res lett, 2013; 8(1): 1-7.
Yin N, Zhang Y, Yun Z, Liu Q, Qu G, Zhou Q, Hu L, Jiang G. Silver Nanoparticle Exposure Induces Rat Motor Dysfunction through Decrease in Expression of Calcium Channel Protein in Cerebellum. Toxicol Lett, 2015.

Yoshihisa Y, Honda A, Zhao QL, Makino T, Abe R, Matsui K, Shimizu H, Miyamoto Y, Kondo T, Shimizu T. Protective Effects of Platinum Nanoparticles against Uv-Light-Induced Epidermal Inflammation. Exp Dermatol, 2010 19(11): 1000-1006.

Yoshiura $Y$, Izumi $H$, Oyabu $T$, Hashiba $M$, Kambara $T$, Mizuguchi Y, Lee BW, Okada T, Tomonaga T, Myojo T. Pulmonary Toxicity of Well-Dispersed Titanium Dioxide Nanoparticles Following Intratracheal Instillation. J Nanopart Res, 2015; 17(6): 1-11.

Zhang L, Laug L, Munchgesang W, Pippel E, GöSele U, Brandsch M, Knez M. Reducing Stress on Cells with ApoferritinEncapsulated Platinum Nanoparticles. Nano letters, 2009; 10(1): 219223.

Zheng W, Jiang B, Hao Y, Zhao Y, Zhang W, Jiang X. Screening Reactive Oxygen Species Scavenging Properties of Platinum Nanoparticles on a Microfluidic Chip. Biofabr, 2014; 6(4): 045004 .

\section{How to cite this article:}

Fatimah Yusof, Noor Akmal Shareela Ismail. Antioxidants effects of Platinum Nanoparticles: A Potential Alternative Treatment to Lung Diseases. J App Pharm Sci, 2015; 5 (07): 140-145. 